\title{
Thyroid hormone action in the developing testis: intergenerational epigenetics
}

\author{
Arturo Hernandez ${ }^{1,2,3}$ and $\mathbf{M}$ Elena Martinez ${ }^{1}$ \\ ${ }^{1}$ Center for Molecular Medicine, Maine Medical Center Research Institute, Maine Medical Center, Scarborough, Maine, USA \\ ${ }^{2}$ Graduate School for Biomedical Science and Engineering, University of Maine, Orono, Maine, USA \\ ${ }^{3}$ Department of Medicine, Tufts University School of Medicine, Boston, Massachusetts, USA
}

Correspondence should be addressed to A Hernandez: hernaa@mmc.org

\begin{abstract}
Male fertility involves the successful transmission of the genetic code to the next generation. It requires appropriately timed cellular processes during testis development, adequate support of spermatogenesis by hormonal cues from the reproductive axis and cellular cross-talk between germ and somatic cells. In addition to being the vessel of the father's genome, increasing evidence shows that the mature sperm carries valuable epigenetic information - the epigenome - that, after fecundation, influences the development of the next generation, affecting biological traits and disease susceptibility. The epigenome of the germ line is susceptible to environmental factors, including exogenous chemicals and diet, but it is also affected by endogenous molecules and pathophysiological conditions. Factors affecting testis development and the epigenetic information of the germ line are critical for fertility and of relevance to the non-genetic but heritable component in the etiology of complex conditions. Thyroid hormones are one of those factors and their action, when untimely, produces profound effects on the developing testis, affecting spermatogenesis, steroidogenesis, testis size, reproductive hormones and fertility. Altered thyroid hormone states can also change the epigenetic information of the male germ line, with phenotypic consequences for future generations. In the context of past literature concerning the consequences of altered thyroid hormone action for testis development, here we review recent findings about the pathophysiological roles of the principal determinants of testicular thyroid hormone action. We also discuss limited work on the effects of thyroid hormone on the male germ line epigenome and the implications for the intergenerational transmission of phenotypes via epigenetic mechanisms.
\end{abstract}

\author{
Key Words \\ - thyroid hormone \\ - thyroid hormone \\ receptors \\ - deiodinases \\ - Thra \\ - Thrb \\ - Dio2 \\ - Dio3 \\ - developing testis \\ - transgenerational \\ epigenetics \\ - Sertoli cells \\ - spermatogonia \\ - Leydig cells \\ - spermatogenesis \\ - gonadal axis \\ - steroidogenesis \\ - male fertility \\ - retinoic acid
}

Journal of Endocrinology (2020) 244, R33-R46

\section{Introduction}

Testicular development and function are critical for normal spermatogenesis and male reproduction. The growth and maturation of the testes require the timely occurrence of multiple processes of cell proliferation, differentiation and cross-talk to ensure adequate cell function and hormone action in testicular tissue to support the maturation of germ cells into functional sperm (Makela et al. 2019).
The disruption of these processes may impair spermatogenesis and compromise male reproductive function. Understanding these processes and the factors that disrupt them is more relevant than ever, considering the continuous decrease in sperm quantity and quality observed in humans during the last decades (Levine et al. 2017). 
Reproduction not only implies the accurate transmission of the genetic code to the next generation. Sperm can carry a wealth of non-genetic (epigenetic) information that reflects the variable environmental and pathophysiological circumstances of an individual (Dunn et al. 2005, Hochberg et al. 2011, GuerreroBosagna \& Skinner 2012). Importantly, this epigenetic information may also influence the development, physiology and disease susceptibility of descendants. The intergenerational transmission of epigenetic information may partly explain the etiology of complex human conditions that exhibit a high degree of heritability but for which genetic factors alone fall short of explaining a majority of clinical cases (Koch 2014a).

In this context of testis development and intergenerational transmission of epigenetic information, thyroid hormones (TH) have pleiotropic effects in mammalian systems, and the developing testis is also a critical target organ (Hernandez 2018b). Alterations in $\mathrm{TH}$ status and signaling have profound effects on multiple cellular processes and functions of the testis, especially during development, ultimately impacting male fertility. In addition, limited but consistent evidence reveals an influence of $\mathrm{TH}$ on the epigenetic information of the germ line and the biological traits of descendants. Here, we review the most critical observations about the effects of TH on the developing testis and the implications for male reproduction. We further highlight key findings concerning the intergenerational epigenetic effects of $\mathrm{TH}$ on the pathophysiology of descendants.

\section{Thyroid hormone action in the developing testis}

\section{Basic mechanisms regulating thyroid hormone action}

The canonical mechanism of $\mathrm{TH}$ action involves the binding of the most active $\mathrm{TH}, 3,5,3^{\prime}$-triiodothyronine (T3), to its nuclear receptors. These receptors are DNAbinding transcription factors and are encoded by two different genes, Thra and Thrb (Pascual \& Aranda 2013). Upon receptor binding and subsequent cofactor recruitment and chromatin modifications, T3 regulates the transcription of target genes (Pascual \& Aranda 2013).

Prior to nuclear receptor binding, T3 secreted by the thyroid gland into the circulation can enter the target cell via cell membrane specific transporters, among which mono-carboxylate transporter 8 (Mct8 or Slc16a2) shows the highest affinity for T3 transport (Heuer \& Visser 2013). In addition, T3 can be generated in peripheral tissues from thyroxine (T4), which is produced by the thyroid gland in more abundance than T3 and is largely considered a prohormone for canonical signaling, as its affinity for thyroid hormone receptors is approximately 10\% that of T3. The conversion of $\mathrm{T} 4$ to $\mathrm{T} 3$ is accomplished by the type 1 and type 2 deiodinases (DIO1 and DIO2, respectively), and their action may modify local T3 availability as well as contribute to circulating levels of TH (St Germain et al. 2009).

Finally, the type 3 deiodinase (DIO3) converts both T3 and T4 into metabolites with very low affinity for the $\mathrm{TH}$ receptors, effectively clearing $\mathrm{TH}$ and reducing $\mathrm{T} 3$ signaling (Charalambous \& Hernandez 2013). Thus, it is increasingly appreciated that T3 action does depend not only on circulating levels of $\mathrm{TH}$, but also on the complement of transporters (Heuer \& Visser 2009), deiodinases (Bianco et al. 2019), receptors (Forrest \& Visser 2013) and receptor cofactors (Astapova \& Hollenberg 2013) present in a particular cell or tissue. This complement of factors can markedly enhance or reduce local T3 action in a manner that is largely independent of circulating levels of $\mathrm{TH}$ (Ng et al. 2004).

\section{Effects of altered TH status on the developing testis}

This subject has been recently reviewed in more detail (Wagner et al. 2008, Hernandez 2018a,b). Here we highlight the most important findings in the context of the present article.

\section{Developmental thyrotoxicosis}

Probably the first observation of testicular abnormalities as a result of $\mathrm{TH}$ excess (thyrotoxicosis) during development was reported in the rat model of neonatal $\mathrm{T} 4$ administration ('neo T4'). In this model, newborn rats were administered large doses of T4 daily for 4-10 days after birth (Bakke et al. 1975, Martin \& Moberg 1981). This protocol resulted in very high neonatal levels of serum T3 and T4 (Martin \& Moberg 1981). Neo-T4 rats exhibited growth retardation and developmental delays and, as adults, moderate central hypothyroidism and an abnormal set-point and physiological response of the hypothalamic-pituitarythyroid (HPT) axis. They also exhibited a significant reduction in testis size (Bakke et al. 1975).

Similar mouse models of $\mathrm{TH}$ administration during neonatal life have also shown a decrease in testis size (Cooke et al. 1994). This is largely due to T3 causing an https://joe.bioscientifica.com

https://doi.org/10.1530/JOE-19-0550 (c) 2020 Society for Endocrinology Published by Bioscientifica Ltd.
Printed in Great Britain 
arrest of Sertoli cell (SC) proliferation (van Haaster et al. 1993, Palmero et al. 1995), a critical process in the testis that is affected by different molecular pathways (Holsberger \& Cooke 2005, Meroni et al. 2019), including those dependent on TH. The small adult testis size and increased levels of follicle-stimulating hormone (FSH) caused by neonatal T3 administration can be fully normalized by a genetic loss of functional THRA (Holsberger et al. 2005b), demonstrating that this receptor is the main mediator of the testicular effects caused by neonatal thyrotoxicosis.

T3 excess also increases gonocyte differentiation, reduces the proliferation of spermatogonia and may promote the apoptosis of germ cells (Boulogne et al. 2003, Rijntjes et al. 2008, Faraone-Mennella et al. 2009) in the neonatal testis.

\section{Hypothyroidism}

Developmental hypothyroidism also leads to consistent abnormalities in testis development and the hormonal pathophysiology of the gonadal axis (Hernandez 2018b). The occurrence and severity of these abnormalities may vary depending on the degree and length of the hypothyroidism and the stage of development affected (from early neonatal to pubertal age). However, the observations consistently show a delay in SC differentiation, leading to increased SC number and testis size in adulthood (Bunick et al. 1994, Cooke et al. 1994, Sakai et al. 2004, Oluwole et al. 2013), along with alterations in the serum levels of testosterone, progesterone and prolactin (Kimura \& Furudate 1996, Maran et al. 2000).

Developmental hypothyroidism also affects spermatogenesis, by reducing the differentiation of spermatogonia (Kirby et al. 1996, Tousson et al. 2011), although this may result in increased sperm production in adulthood due to a larger reserve of undifferentiated germ cells (Auharek \& de Franca 2010).

Insufficient neonatal levels of TH cause a reduction in the number of mesenchymal cells that differentiate into Leydig cell (LC) progenitors and ultimately into adult LCs (Rijntjes et al. 2009, Kobayashi et al. 2014). This effect is associated with decreased expression of steroidogenic genes including Sf1 (Nr5a1), Star, Cyp11a1 and Hsd17b3 (Sarkar \& Singh 2017a).

In summary, with some caveats, T3 signaling during testis development generally promotes the differentiation of germ and somatic cells, ultimately affecting steroidogenesis, spermatogenesis, testis size, testicular cell homeostasis and the hormonal physiology of the adult gonadal axis.

\section{Determinants of TH action in the developing testis}

A first determinant of circulating $\mathrm{TH}$ and $\mathrm{T} 3$ action in the developing testis is the HPT axis. Mammalian development is characterized by a steady increase in circulating levels of TH until the full maturation of the HPT axis. In rodents (and humans), TH levels in early fetal development are generally much lower than those in adults (Morreale de Escobar et al. 1990). This is due to the absence of thyroid gland function at that age and the effective clearance of maternal $\mathrm{TH}$ by DIO3, which is highly expressed in uterine decidual tissue, placenta and fetal tissues (Galton et al. 1999, Huang et al. 2003). Murine TH levels peak around 2-3 weeks after birth, with several factors accounting for the systemic increase in TH during mammalian development. These include: the reduction of DIO3 activity in most tissues as development progresses (Hernandez 2013), the start of thyroid function in late gestation (Ruiz de Oña et al. 1991), the neonatal maturation of the hypothalamic-pituitary thyroid axis (Dussault \& Labrie 1975) and the developmental increase in DIO1 and DIO2 expression, mostly in liver and brain (Bates et al. 1999), which aid in the generation of T3 from circulating T4. During fetal and neonatal life, tissuespecific changes in the expression of TH transporters, receptors and mostly deiodinases are often responsible for timely and abrupt changes in local levels of TH action. These changes may markedly depart from TH levels in the circulation as they meet the specific T3 needs of particular developmental processes ( $\mathrm{Ng}$ et al. 2004).

In the face of rising levels of $\mathrm{TH}$ in the serum, the developing testis expresses its own local determinants of TH action, most notably the transporter MCT8, the deiodinase DIO3 (Martinez et al. 2016b) and the receptor THRA (Jannini et al. 1990, 1994, Canale et al. 2001). Recently published comprehensive transcriptomic data across tissues, species and developmental ages (Fig. 1) (Cardoso-Moreira et al. 2019) indicate that the testicular expression of Mct8, Dio3 and Thra mRNAs in mice and humans (and other species) is higher during development than in post-pubertal life (Cardoso-Moreira et al. 2019). Despite this general parallelism, the translation to humans of findings from rodent studies should be taken with caution given the marked difference between these species in the velocity of maturation of the testis and reproductive function, making models of human testis development difficult to establish (Hutka et al. 2017, Tharmalingam et al. 2018). In addition, these human datasets lack information on the second half of gestation and on the childhood years during which the human gonadal axis 

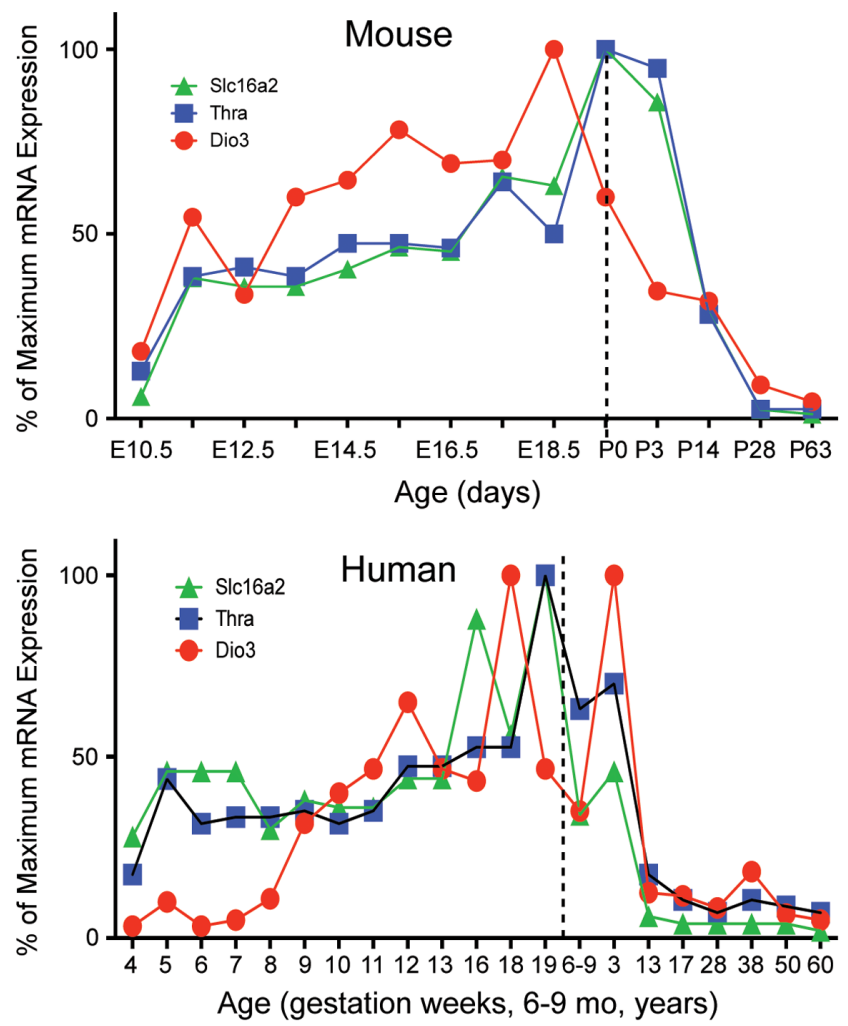

Figure 1

Testicular mRNA expression profile of key determinants of thyroid hormone action. Figures are built based on transcriptomic datasets in developing tissues (Cardoso-Moreira et al. 2019) (https://apps.kaessma nnlab.org/evodevoapp/) and expressed as a percentage of the maximum expression found. Dotted line indicates birth. (Note that important aspects of testicular development may differ between mice and humans and that human data points available in this work skip the second half of gestation and pre-pubertal childhood years.)

remains relatively dormant. Overall, mouse data on the developmental testis transcriptomes are consistent with specific published data on the testicular expression of these genes at both the mRNA and protein levels (Tagami et al. 1990, Jannini et al. 1994, Martinez et al. 2016b). The marked decrease in the testicular expression of Thra and Mct8 in adult life suggests that testicular sensitivity to TH at this age is much more limited than during development.

Although the THRB receptor can be detected in the testis and spermatocytes (Vanacker et al. 1998, Rao et al. 2003), its mRNA abundance is less than 5\% that of THRA and its functional significance is yet to be determined. Similarly, absolute levels of testicular Dio2 mRNA are very low, even though a sharp increase is noted in late neonatal life and adulthood (Fig. 1) (Bates et al. 1999, Cardoso-Moreira et al. 2019). The expression of the DIO1 in the testis is negligible.

In summary, the abundance of transporter MCT8 and receptor THRA suggests that the developing testis is highly sensitive to TH action (Fig. 1). On the other hand, the relatively high expression of Dio3 indicates that TH action in the testis needs to be appropriately limited during perinatal life. Initial observations in transgenic mouse models provide some insight into the influence of these genes on testis development and function.

\section{THRA and DIO3 deficiencies}

One would predict that the consequences of a deficiency in THRA, the main TH receptor in the testis and responsible for mediating T3 action in this tissue, would be consistent with those in neonatal hypothyroidism. Indeed, global and SC-specific dominant negative THRA mutations in mice produce small testes and a extended period of SC proliferation (Fumel et al. 2012). Comparable results have been described in mouse models lacking a p43 isoform of THRA in the mitochondria or expressing a dominant negative THRA from the aromatase promoter (Fumel et al. 2013, 2015).

On the other hand, DIO3, which exhibits a marked developmental pattern of expression in most tissues (Hernandez 2005) including the testis, (Martinez et al. 2016b) (Fig. 1), would protect the immature testis from premature T3 action. Mice with global DIO3 deficiency (Dio3-/- mice) exhibit impaired TH clearance and subsequent serum thyrotoxicosis during fetal and neonatal life (Hernandez et al. 2006), resulting in a 75\% reduction in testis size by adult age (Martinez et al. 2016b). This is consistent with observations in pharmacological models of neonatal thyrotoxicosis (Bakke et al. 1975, Holsberger et al. 2005b). However, in the latter models, the observed reduction in testis size is more modest despite achieving much higher levels of neonatal T3 in the circulation (Martin \& Moberg 1981, Hernandez et al. 2006). This suggests that the active DIO3 present in those models is still able to provide substantial protection from T3 excess.

Also consistent with previously published observations in models of neonatal thyrotoxicosis, Dio3-/- mice exhibit proliferation arrest of SCs and premature lumen formation in seminiferous tubules (Martinez et al. 2016b). They further show impaired spermatogenesis, delayed puberty, poor fertility and hormonal abnormalities in the reproductive axis. The latter include reduced serum testosterone, elevated serum levels of FSH and LH and elevated mRNA expression of hypothalamic Gnrh and pituitary Fshb and Lhb (Martinez et al. 2016b). It remains to be determined to what extent the central abnormalities in the reproductive axis of Dio3-/- mice result from direct effects of T3 in the hypothalamus and pituitary or from abnormal testicular hormones feedback during development. 
Genes regulated by $\mathrm{T} 3$ in the neonatal testis The sensitivity of the developing testis to $\mathrm{TH}$ and the severe testicular and reproductive phenotype of Dio3-/- mice imply broad and profound underlying changes in gene expression patterns. Gene expression profiling of the postnatal day 5 Dio3-/- testis identified $5 \mathrm{~K}+$ genes with altered expression when compared to wild type littermates (Martinez et al. 2019). Genes showing increased expression in the neonatal Dio3-/- testis were enriched in biological and ontology terms associated with cell membrane function, while genes repressed by $\mathrm{TH}$ included cell cycle genes and most histone genes and were greatly enriched in terms associated with nuclear function, mitosis and chromatin structure (Martinez et al. 2019). These results are consistent with previous studies suggesting a general role of $\mathrm{T} 3$ in promoting testis cell differentiation and halting cell proliferation.

Although T3 generally induces the differentiation of most types of testicular cells, it is SCs that are most affected, as extensively showed in pharmacological models of neonatal thyrotoxicosis mentioned above. In the Dio3-/- testis, down-regulation of anti-mullerian hormone $(A m h)$ and many mitosis-related genes and up-regulation of genes associated with the establishment of the blood-testis barrier such as Connexin 43,
Cldn11 and Esyt3 (Sarkar \& Singh 2017b, Martinez et al. 2019, Meroni et al. 2019) are consistent with proliferation arrest and subsequent differentiation of SCs.

Pathway analysis of differentially expressed genes in the neonatal Dio3-/- testis provides interesting mechanistic insight (Table 1). Pathways predicted as activated include those regulated by Trp53 and Cdkn1a (also p21), androgen receptor, dexamethasone and progesterone. Of these, p21 and androgen signaling have been previously shown to induce the differentiation of SCs (Holsberger \& Cooke 2005, Holsberger et al. 2005a, Meroni et al. 2019). Additional pathways predicted as activated include those regulated by lipopolysaccharide, interleukin 6, tumor necrosis factor and interferon gamma (Table 1), which are suggestive of inflammation. In contrast, pathways predicted to be inhibited in the neonatal Dio3-/- testis are mostly involved in cell proliferation (Table 1 ) including $17 \beta$-estradiol, which has been shown to enhance SC proliferation (Meroni et al. 2019).

One pathway predicted to be strongly upregulated is that of tretinoin, an agonist of the retinoic acid (RA) receptors. This is particularly interesting, as RA signaling not only promotes SC differentiation (Meroni et al. 2019), but also is known to be a main driver of spermatogenesis (Evans et al. 2014). Furthermore, the regulatory effects

Table 1 Regulated pathways in postnatal day 5 Dio3-/- testis.

\begin{tabular}{l} 
Upstream regulator \\
\hline AR \\
IL6 \\
TNF \\
LPS \\
DEX \\
Progesterone \\
TP53 \\
TGFB1 \\
tretinoin \\
TPA \\
CDKN1A \\
CEBPB \\
CTNNB1 \\
IFNG \\
ERBB2 \\
CSF2 \\
PTGER2 \\
RABL6 \\
beta-Estradiol \\
FOXM1 \\
AREG \\
TBX2 \\
EP400 \\
T3 \\
TPE 19
\end{tabular}

\begin{tabular}{l} 
Name/type of compound \\
\hline Androgen receptor \\
Interleukin 6 \\
Tumor necrosis factor \\
Lipopolysacharide \\
Dexamethasone \\
Progesterone \\
Transformation related protein 53 \\
Transforming growth factor beta \\
Retionic acid receptor agonist \\
Phorbol ester \\
Cyclin-dependent Kinase inhibitor 1 a \\
CAAT-enhancer binding protein beta \\
beta-Catenin \\
Interferon gamma \\
erb-b2 receptor tyrosine kinase 2 \\
Colony stimulating factor 2 \\
Prostaglandin E receptor 2 \\
RAB, RAS oncogene family like 6 \\
17 $\beta$-Estradiol \\
forkhead box M1 \\
Amphiregulin \\
T-box transcription factor 2 \\
E1A binding protein P400 \\
L-triiodothyronine
\end{tabular}

\begin{tabular}{l} 
Pathway prediction \\
\hline Activation \\
Activation \\
Activation \\
Activation \\
Activation \\
Activation \\
Activation \\
Activation \\
Activation \\
Activation \\
Activation \\
Activation \\
Activation \\
Activation \\
Inhibition \\
Inhibition \\
Inhibition \\
Inhibition \\
Inhibition \\
Inhibition \\
Inhibition \\
Inhibition \\
Inhibition \\
Activation \\
\hline
\end{tabular}

\begin{tabular}{c}
\hline Z-score \\
\hline 2.119 \\
3.747 \\
4.32 \\
3.31 \\
3.378 \\
2.647 \\
3.664 \\
2.706 \\
6.059 \\
3.916 \\
3.16 \\
2.329 \\
2.263 \\
3.8 \\
-4.661 \\
-2.264 \\
-5.364 \\
-5.303 \\
-2.11 \\
-3.949 \\
-3.524 \\
-5.282 \\
-4.021 \\
3.132 \\
\hline
\end{tabular}

\begin{tabular}{l}
\hline $\boldsymbol{P}$ value \\
\hline $2.53 \mathrm{E}-36$ \\
$5.03 \mathrm{E}-30$ \\
$7.74 \mathrm{E}-29$ \\
$9.02 \mathrm{E}-29$ \\
$2.88 \mathrm{E}-26$ \\
$2.75 \mathrm{E}-24$ \\
$1.21 \mathrm{E}-23$ \\
$2.16 \mathrm{E}-23$ \\
$7.25 \mathrm{E}-22$ \\
$5.16 \mathrm{E}-19$ \\
$6.1 \mathrm{E}-19$ \\
$1.64 \mathrm{E}-18$ \\
$2.04 \mathrm{E}-17$ \\
$4.25 \mathrm{E}-17$ \\
$1.34 \mathrm{E}-26$ \\
$2.17 \mathrm{E}-24$ \\
$1.14 \mathrm{E}-23$ \\
$1.47 \mathrm{E}-22$ \\
$2.88 \mathrm{E}-20$ \\
$4.38 \mathrm{E}-19$ \\
$1.08 \mathrm{E}-17$ \\
$8 \mathrm{E}-17$ \\
$1.12 \mathrm{E}-16$ \\
$1.53 \mathrm{E}-09$ \\
\hline
\end{tabular}

Top upstream regulators identified by Ingenuity Pathway Analysis with lowest $P$ values and Z-scores $>2$ or $<-2$. Parameters obtained for the T3 pathway are shown below for reference.

$$
\begin{array}{lr}
\text { https://joe.bioscientifica.com } & \text { (c) } 2020 \text { Society for Endocrinology } \\
\text { https://doi.org/10.1530/JOE-19-0550 } & \text { Published by Bioscientifica Ltd. } \\
\text { Printed in Great Britain }
\end{array}
$$


of DIO3 deficiency on a subset of genes specific to spermatogonia strongly correlate with those produced by RA administration (Evans et al. 2014, Martinez et al. 2019). This suggests that T3 may enhance RA regulation of spermatogenesis. This can be facilitated by the downregulation of DIO3 by RA (Evans et al. 2014).

Although $\mathrm{TH}$ positively regulates steroidogenesis in the prepubertal testis (Sarkar \& Singh 2017a), results from early neonatal Dio3-/- testis indicate a marked repression of Hsd17b3 and Hsd17b1 (Martinez et al. 2019), which are steroidogenic genes responsible for the last step in testosterone synthesis. However, other steroidogenic genes such as Star and Cyp11a1 were up-regulated in Dio3-/- testis. It is possible that certain steroidogenic genes are not regulated in the same manner in the neonatal and pre-pubertal testis, possibly because fetal and adult LCs respond differently to T3. In this regard, markers of fetal LC progenitors (McClelland et al. 2015) were largely down-regulated in Dio3-/- neonatal testis (Martinez et al. 2019), suggesting a role for $\mathrm{T} 3$ in the differentiation of fetal LCs. The expression changes in steroidogenic genes may also reflect impairment in the maturation of adult LCs caused by T3. The ultimate impact on perinatal serum testosterone remains to be determined.

The overlap of T3 regulated genes in Dio3-/- testis and in the testis of newborn mice carrying a dominant negative Thra mutation in SCs (Chatonnet et al. 2014) is consistent, but also revealed a few genes apparently regulated in opposite directions by TH signaling (Martinez et al. 2019). This may reflect differences between models in the developmental windows of response or in the populations of cells that express those genes rather than a direct regulation.

\section{Genetic rescue of the testis phenotype of DIO3} deficiency Diminishing $\mathrm{TH}$ action by genetic inactivation of other determinants of $\mathrm{TH}$ signaling ameliorates the severe testicular phenotype caused by global DIO3 deficiency. Dio3-/- mice lacking THRA exhibit normal size testis and normalized T3-dependent expression of testicular genes (Martinez et al. 2016b), further demonstrating that this receptor subtype mediates most of the detrimental testicular effects of T3 excess, as shown before in a pharmacological mouse model of neonatal thyrotoxicosis (Holsberger et al. 2005b).

The testis phenotype of the Dio3-/- mice was improved, but not fully normalized, by a global deficiency in the MCT8 transporter (Martinez et al. 2016b). The partial rescue of the phenotype included testis size and T3-dependent expression genes in the neonatal testis. Although Mct8
mRNA is present in several cell types of the neonatal testis according to single cell RNA seq data (Evans et al. 2014, Green et al. 2018), the function of MCT8 in SCs probably accounts for most of the phenotypic rescue. Some adult parameters in testis, pituitary and hypothalamus of Dio3-/- mice were not improved by global MCT8 deficiency, suggesting additional, more complex effects in tissues of the reproductive axis.

Similarly, a global loss in DIO2 also improved to a partial extent the testis size phenotype of Dio3-/- mice, as well as their testicular neonatal expression of $\mathrm{T} 3$ regulated genes (Martinez et al. 2016b). Since transcriptome datasets and enzymatic activity data indicates that DIO2 is expressed at very low levels in the developing testis, it is likely that the observed phenotypic rescue derives from a reduction in systemic T3 availability due to lack of DIO2 function in other neonatal tissues.

DI03 deficiency in germ cells The observations in Dio3-/- mice raise an important question about the cellular expression of Dio3 in the testis. Dio3 expression in SCs seems to be functionally irrelevant, as genetic inactivation of DIO3 in SCs does not cause any change in DIO3 activity in the neonatal testis (Martinez et al. 2019). However, Dio3 inactivation in neonatal spermatogonia (using a mouse model with a floxed Dio3 and a cre transgene regulated by the Stra 8 promoter) reduces testicular DIO3 activity by $90 \%$ (Martinez et al. 2019). This observation indicates that spermatogonia are the cell type predominantly expressing Dio3 during testicular development and possibly in the adult testis. As the marked reduction in testicular Dio3 expression in adulthood (Martinez et al. $2016 b$ ) is consistent with the much lower percentage that undifferentiated spermatogonia represent in the cell population of the adult testis. It is unknown whether this finding is translatable to humans, as no information is available about what testicular cell types in humans express DIO3 or other determinants of TH action. A recent published work describes single cell RNA-sequencing data on the human testis during puberty and other ages and could provide important insights in this regard, but the data could not be timely analyzed for the present review (Guo et al. 2020).

Consistent with the presence of DIO3 specifically in early stage spermatogonia, genes down-regulated in the testis of Dio3-/- neonates exhibit an enrichment in markers specific to stage III spermatogonia (Martinez et al. 2019). Treatment with retinoic acid in a synchronized model of neonatal spermatogenesis results in a marked decrease in Dio3 expression (Evans et al. 2014), suggesting 
a decrease in Dio3 expression at the initial stages of spermatogenesis. Furthermore, although expressed at lower levels in the adult testes, Dio3 expression peaks at stages $2-7$ of the seminiferous epithelium, when undifferentiated spermatogonia accumulate (Green et al. 2018). Finally, single cell RNA sequencing data also show germ cell Dio3 expression peaking perinatally when the percentage of undifferentiated spermatogonia is highest in the testis (Law et al. 2019).

Neonatal spermatogonia-specific inactivation of Dio3 is sufficient to cause local thyrotoxicosis in the testis, as indicated by reduced testis size at weaning age and expression changes in TH-dependent genes (Martinez et al. 2019). Importantly, this local excess of $T 3$ affects the expression of genes specific to SCs and LCs, indicating that TH-dependent gene expression patterns in testicular somatic cells are influenced by spermatogonial Dio3 (Fig. 2), with consequences for steroidogenic enzymes and SC differentiation and testis growth (Martinez et al. 2019). These observations reveal a cross-talk between testicular cells that involves the regulation of $\mathrm{T} 3$ action.

\section{Intergenerational epigenetic effects of thyroid hormone}

\section{Unidentified etiology of complex conditions}

A large component in the etiology of many complex human conditions remains undefined. Schizophrenia, autistic spectrum disorders, infertility, cardiovascular

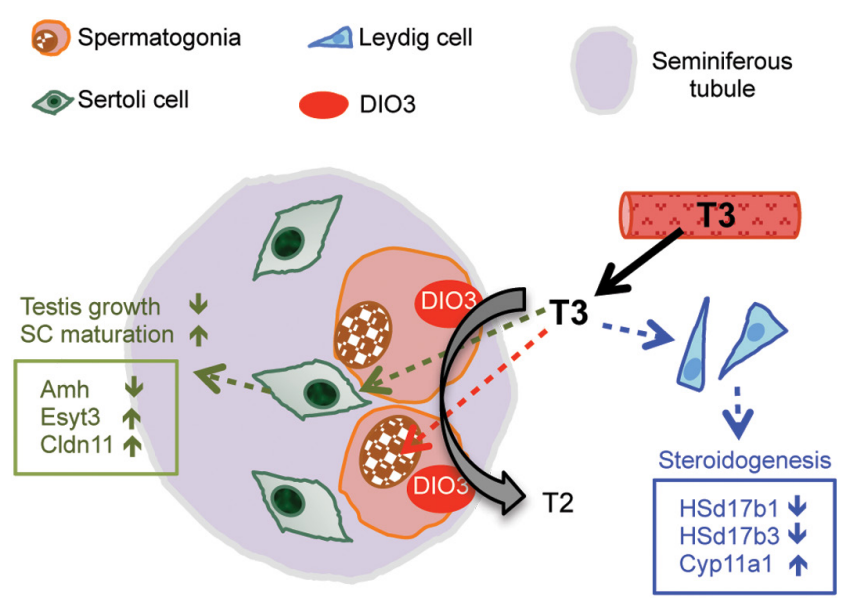

Figure 2

$\mathrm{DIO} 3$ role in the developing testis. By converting T3 into T2 (thick grey arrow), spermatogonial DIO3 modulates thyroid hormone action in different testicular cells (dotted arrows), influencing the expression of genes in neighboring cells involved in LC steroidogenesis (blue color) and SC proliferation and differentiation (green color) (Martinez et al. 2019). disease, metabolic syndrome and obesity are but a few examples of disorders that exhibit a relatively high heritability according to familial studies (Lee et al. 2011), but for which genetic factors identified in genome-wide association studies (GWAS) can only explain a minority of actual clinical cases.

This marked discrepancy between disease heritability and genetic variation initiated the quest to identify the origins for the 'missing heritability' of such conditions (Lee et al. 2011, Koch 2014b), which can be partly explained by the inheritance of altered epigenetic information. In this regard, increasing evidence is showing that paternal and maternal germ lines carry a complement of epigenetic information (the epigenome, in the broadest sense) that influences gene expression programs and development in the offspring, generating phenotypes of relevance to disease (Anway et al. 2005, Skinner 2007, Guerrero-Bosagna \& Skinner 2012). Critically, the germ cell epigenome, including DNA methylation patterns (Waterland et al. 2007), microRNA population, chromatin signatures, concentration of metabolites and other small molecules (Rodgers et al. 2013, 2015), is susceptible to change as a result of environmental influences such as paternal diet, stress and glucocorticoid exposure, infection and inflammatory states and exposure to drugs or chemicals in the environment.

In this context, the extensive roles of $\mathrm{TH}$ in development and metabolism, its role in influencing the chromatin landscape and its targeting of the developing testis and spermatogonia all make a strong case for these hormones as an important influence on the germ line epigenome. These effects of TH are of clinical relevance, as abnormal TH states frequently occur in humans due to thyroid disease (McLachlan \& Rapoport 2014) or to exposure to chemicals that disrupt $\mathrm{TH}$ physiology and signaling (Brent et al. 2007).

\section{Intergenerational epigenetic effects of thyroid hormones: seminal observations}

As mentioned previously, the work of Bakke et al. using the rat 'neo-T4' model was one of the first to report a reduction in testis size as a result of developmental overexposure to TH (Bakke et al. 1975). Interestingly, using this animal model in two seminal articles published in the early seventies, Bakke and colleagues were also the first to our knowledge to report intergenerational epigenetic effects of altered TH states (Bakke et al. 1976). These investigators observed that the offspring of neo-T4 male rats (Fig. 3A) manifested delayed eye opening, enlarged thyroid gland 
A

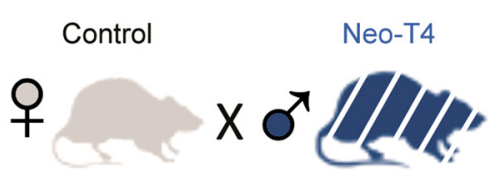

F1

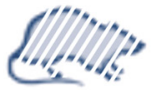

Both sexes: Delayed eye opening;

Reduced weight at weaning; Enlarged

thyroid gland

Females: Increased adult BW and

decreased pituitary size

Males: Increased SME TSH and reduced

serum and SME TSH in response to TRH
B

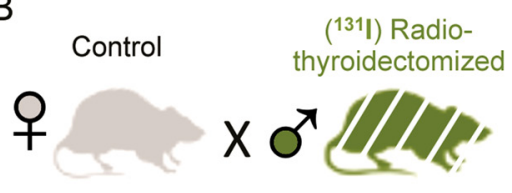

F1

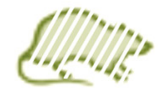

Both sexes: Delayed eye opening;

Reduced weight at weaning, altered

gonadal weight

Females: Enlarged thyroid gland

Males: Increased adult BW and enlarged pituitary gland

\begin{abstract}
Figure 3
Phenotypes in the offspring of male rats with altered thyroid status. (A and B) Phenotypes in the offspring of male rats overexposed to thyroid hormone during development ('neo-T4' model, A) or made hypothyroid as adults (B). BW, body weight; TSH, thyroid stimulating hormone; TRH, thyrotropin releasing hormone; SME, stalkmedian eminence (Bakke et al. 1976).
\end{abstract}

(goiter) and reduced weight at weaning. Other noted abnormalities were sexually dimorphic and included increased adult body weight and reduced pituitary size (females), increased stalk-median eminence thyroid stimulating hormone (SME-TSH) and reduced serum and SME TSH in response to stimulation by thyropin releasing hormone (TRH) (males) (Bakke et al. 1976).

Since neo-T4 animals experience thyrotoxicosis during neonatal life leading to moderate central hypothyroidism in adulthood, Bakke and colleagues also studied the offspring of male with severe, adult-onset hypothyroidism accomplished by radio-ablation of the thyroid gland (Fig. 3B). Both sexes of this offspring also exhibited delayed eye opening and reduced weight at weaning, but also alterations in gonadal weight (Bakke et al. 1976). Again, these mice also showed sexually dimorphic features, including goiter in females and increased adult body weight and pituitary size in males.

The authors could barely speculate about a potential mechanism to explain these observations at a time when the word 'epigenetic' was a rarity. However, their work is a critical precedent supporting the notion that altered $\mathrm{TH}$ status modifies the epigenetic information of the male germ line, affecting phenotypic traits in the offspring.

\section{Intergenerational epigenetic effects of DIO3 deficiency}

Intergenerational epigenetic effects have also been observed using a mouse model of DIO3 deficiency (Martinez et al. 2018) (Fig. 4). This is not surprising given the large phenotypic similarities and testis outcomes in neo-T4 rats and Dio3-/- mice.

Studies on wild type, second-generation descendants of Dio3-/- mice through the paternal line reveal alterations in neonatal patterns of gene expression in several brain regions, including the hypothalamus, striatum and hipocampus (Martinez et al. 2018) (Fig. 4). A disproportionate number of the down-regulated genes were specific to neurons, while a large proportion of up-regulated genes were specific to oligodendrocytes and myelination (Martinez et al. 2018). Since myelination and myelination-related genes are highly dependent on $\mathrm{TH}$ action and correlate with the neonatal increase in systemic and brain $\mathrm{TH}$, intergenerational epigenetic marks controlling the maturation of the HPT axis or local T3 availability in the CNS may have been affected by overexposure to TH in Dio3-/- ancestors. It is also possible that these T3-regulated genes are epigenetically altered as a result of the ancestral exposure, but the modest overrepresentation of known T3-regulated genes among differentially expressed genes in the brain of descendants (Martinez et al. 2018) suggests that the effects observed cannot be only explained by epigenetic alterations in the brain T3 targetome.

The descendants' changes in neonatal brain gene expression were associated with abnormal behavior, including decreased anxiety-like behavior, reduced levels of physical activity and increased marble burying behavior, with no changes in depression-like behavior (Martinez et al. 2018). The first behavioral trait was also described in Dio3-/- mice, while the other three are opposite or inconsistent with the behavioral traits in Dio3-/- ancestors (Stohn et al. 2016). These observations indicate that the intergenerational epigenetic effects of $\mathrm{TH}$ overexposure may lead to a maintenance, correction or reversion of the original ancestors' neurobehavioral phenotypes.

These observations, as well as the previous ones by Bakke's group, suggest that the male germ line of Dio3-/mice and neo-T4 rats is transmitting altered epigenetic information to their offspring and descendants. Consistent with this idea, neonatal germ cells of Dio3-/- male mice 

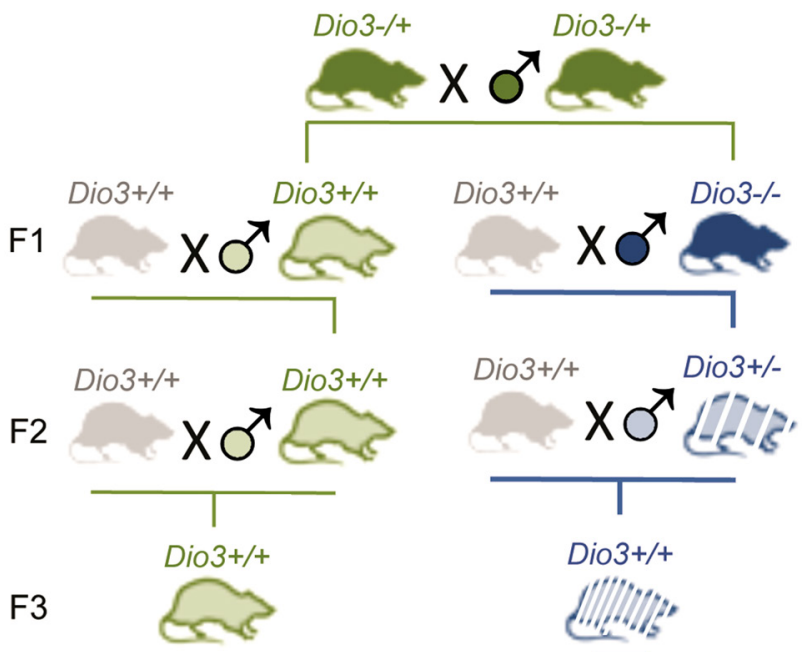

F3

Dio3+/+
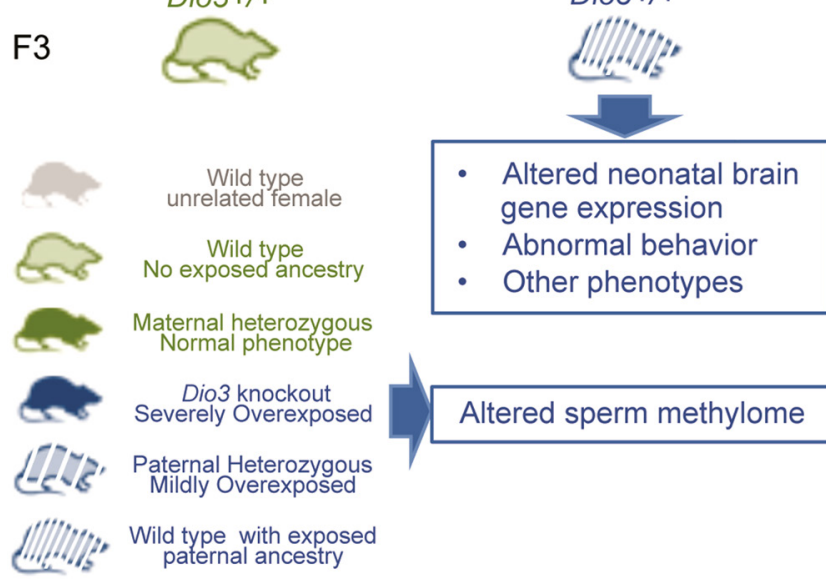

Figure 4

Intergenerational epigenetic effects in descendants of Dio3-/- mice. Male Dio3-/- mice showed alterations in the sperm methylome, and their F2 generation descendants in paternal lineage exhibit abnormal brain gene expression and behavior compared to $\mathrm{F} 2$ generation descendants of male Dio3+/+ littermates (Martinez et al. 2018).

exhibited hypomethylation, and the methylation profile of the mature sperm of these mice was altered (Martinez et al. 2018). Interestingly, the Dio3-/- sperm methylome features a similar number of hypermethylated and hypomethylated $\mathrm{CpG}$ residues across the genome, but exhibits a marked bias toward hypomethylation in CpG islands associated with gene promoters (Martinez et al. 2018). The majority of genes associated with the most profound promoter hypomethylation are specific to brain tissue and implicated in brain development (Martinez et al. 2018) and may contribute to the behavioral abnormalities in descendants. However, for the most part, the hypomethylated genes in ancestral sperm are not the same as the abnormally expressed genes in the brain of descendant neonates. The absence of a major gene overlap in this regard suggests that the abnormal behavioral traits and brain gene expression patterns in Dio3-/- descendants could be secondary to abnormalities in earlier brain developmental processes and/or partially result from alterations in other molecular types of epigenetic information caused by $\mathrm{TH}$ overexposure in ancestors.

Although less studied, available evidence suggests that the female germ line is likewise susceptible to epigenetic changes as a result of TH overexposure. Wild type mice with a Dio3-/- paternal grandmother also exhibit changes in neonatal brain gene expression patterns, and these are strikingly similar to those observed in mice with a Dio3-/paternal grandfather (Martinez et al. 2018). Furthermore, second generation descendants of neo-T4 female rats through the paternal line exhibit similar phenotypes as those in descendants of neo-T4 males (Bakke et al. 1977). These overlapping phenotypes in the descendants of both types of male and female T3-overexposed animals implicate comparable $\mathrm{TH}$-driven epigenetic changes in both the male and female germ lines.

\section{Transgenerational epigenetic inheritance in humans caused by thyroid hormone}

In addition to rodents, evidence for a comparable role for $\mathrm{TH}$ status in transgenerational epigenetic effects has been described in humans. In this regard, Anselmo and colleagues have worked with individuals from different generations of a relatively isolated Azorean population carrying mutations in the TRHB gene (Anselmo et al. 2019). THRB is the receptor that specifically mediates the central negative feedback of TH on the HPT axis (Forrest et al. 1996).

Carrying one copy of this mutation is not sufficient to cause an abnormal TH status. However, due to the especial thyroid function needs during pregnancy, pregnant women carriers develop hyperthyroidism, which may result in excessive $\mathrm{TH}$ action in the fetus. Patients of either sex not carrying the mutation but exposed to an excess of TH in utero because of maternal THRB mutation exhibit as adults a HPT axis with decreased central sensitivity to TH (Fig. 5), as demonstrated by impaired serum TSH suppression by T3 treatment (Srichomkwun et al. 2017). This phenotype is also observed in a mouse model carrying the mutation (Srichomkwun et al. 2017). Interestingly, this physiological impairment is transmitted for two generations along the paternal lineage, but the transmission is halted at any female descendant in the ancestry tree (Anselmo et al. 2019) (Fig. 5).

This study suggests that the epigenetic information of the human male germ line is also affected by a developmental excess of $\mathrm{TH}$, affecting the HPT axis 
F0

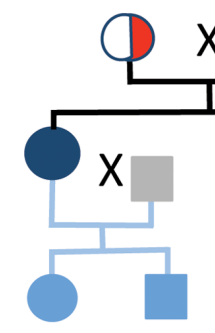

F2

Female carrying a THRB mutation develops hyperthyroidism during pregnancy due to central resistance to $\mathrm{TH}$

Individuals with THRB mutant mother, overexposed to TH during fetal life and with adult impairment in TSH suppression by L-T3

Individuals with THRB mutation ancestry, normal TH during fetal life but adult impairment in TSH suppression by L-T3

Individuals with THRB mutation ancestry, normal TH during fetal life and normal TSH suppression by L-T3

Unrelated individuals with no THRB mutation ancestry

\section{Figure 5}

Epigenetic inheritance of TSH suppression in humans overexposed to thyroid hormones in utero. Genetically normal children of mothers that develop hyperthyroidism during pregnancy due to a THRB mutation exhibit impaired TSH suppression by T3 (F0 generation), and this phenotype is transmitted for two generations (F1 and F2) through the paternal line (darker lines), but not through the maternal line (light lines) (Anselmo et al. 2019).

of non-exposed descendants for two generations and demonstrating stable epigenetic inheritance (Anselmo et al. 2019). It is intriguing why the female germ line is not affected. Perhaps sex differences exist in the timing of germ cell maturation and susceptibility to TH. Alternatively, the maternal germ line may be altered in a different fashion, influencing descendants' phenotypes not yet identified.

The HPT axis phenotype observed in this human model of transgenerational inheritance (Anselmo et al. 2019) is comparable to the phenotype reported in the offspring of neo-T4 male rats (Bakke et al. 1975). In addition, unpublished results in our laboratory indicate an HPT phenotype in descendants of Dio3-/- mice. The consistency of HPT set point phenotypes in three different animal and human models significantly strengthen a case for the epigenetic inheritance of HPT phenotypes as a result of ancestral TH status. This may partly explain the inter-individual variation within the normal clinical range of serum parameters of HPT function (Browning et al. 1986).

Differences between mouse and humans in the physiological regulation and timing of biological processes affecting testicular and reproductive development may lead to inter-species differences in the susceptibility of the germ line to epigenetic alterations caused by abnormal levels of $\mathrm{TH}$ action. The current work of Anselmo and colleagues indicates that fetal life is one such period of susceptibility.

\section{Mechanisms of intergenerational epigenetic effects driven by $\mathrm{TH}$}

Little is known about the molecular underpinnings of the intergenerational epigenetic effects of $\mathrm{TH}$ or other factors. Considering what is known about the canonical signaling pathway of T3 and its effects, and the presence of THRA in male germ cells (Evans et al. 2014), changes in T3 availability in undifferentiated spermatogonia may cause specific changes in the broad epigenetic signature of these cells. Presumably, these changes may be maintained or lead to additional changes in the mature sperm, with consequences for the pathophysiology of the next generation.

The sexual dimorphisms (Bakke et al. 1976) and parental lineage effects (Anselmo et al. 2019) observed in TH-driven intergenerational epigenetic suggest the implication of genes subject to genomic imprinting. This phenomenon involves the establishment of sex-specific germ line epigenetic marks, preferential or exclusive allelic expression and is considered highly susceptible to environmental factors (Jirtle \& Skinner 2007). It is thus intriguing to consider that, as an imprinted gene in mouse and humans (Hernandez et al. 2002, Tsai et al. 2002, Martinez et al. 2016a), Dio3 epigenetic alterations may be contributing to the intergenerational epigenetic effects of T3. Several findings support this hypothesis: Dio3 is strongly up-regulated by T3 in multiple tissues (Barca-Mayo et al. 2011, Hernandez et al. 2012); Dio3 is a critical determinant of the HPT axis set point (Hernandez et al. 2006, 2007), a phenotype involved in T3-driven intergenerational effects; and Dio3 is specifically and highly present in the male germ line (Martinez et al. 2019). Interestingly, contrary to other tissues showing preferential expression from the paternal allele (Charalambous \& Hernandez 2013), Dio3 exhibits biallelic expression in the neonatal testis (Martinez et al. 2019) and, presumably, in spermatogonia.

The evidence currently available thus supports a direct effect of T3 on spermatogonia as likely responsible for its intergenerational epigenetic effects. However, these effects may be secondary to changes in other cellular and biochemical factors that are regulated by T3 systemically or in the testis. Thus, TH has broad effects on metabolism and altered metabolic states are known to cause intergenerational 
epigenetic effects (Zambrano et al. 2005, Godfrey et al. 2010, Nilsson \& Skinner 2015, Skinner 2016). In addition, as reviewed here, T3 may also impact the physiology of somatic cells in the testis, notably LCs and SCs, which exert critical functions in supporting spermatogonia differentiation and could also influence their epigenetic information. Much work is needed to understand the molecular and cellular mechanisms underlying T3-driven germ line epigenetics, and to delineate the developmental gene expression programs and disease-relevant phenotypes that are affected as a result.

\section{Conclusions}

Appropriately timed, cell-specific TH action is essential for normal testis development and to regulate steroidogenesis, spermatogenesis and male fertility. Spermatogonial DIO3 is critically positioned to adequately modulate MCT8and THRA-mediated T3 availability and action in somatic and germ cells of the developing testis, impacting their proliferation and differentiation and the physiology of the male reproductive axis. Abnormal TH levels during development, and possibly during adulthood, can alter the epigenetic information of the male germ line, with consequences for brain gene expression programs, behavior, development and the HPT axis set point of future generations. This may be relevant to the missing heritability of complex conditions in humans, as abnormalities in TH physiology may occur due to thyroid disease or exposure to endocrine disruptors.

\section{Declaration of interest}

The authors declare that there is no conflict of interest that could be perceived as prejudicing the impartiality of this review.

\section{Funding}

This work was partly supported by grants DK095908, MH096050 and DE028732 from the National Institutes of Health.

\section{References}

Anselmo J, Scherberg NH, Dumitrescu AM \& Refetoff S 2019 Reduced sensitivity to thyroid hormone as a transgenerational epigenetic marker transmitted along the human male line. Thyroid 29 778-782. (https://doi.org/10.1089/thy.2019.0080)

Anway MD, Cupp AS, Uzumcu M \& Skinner MK 2005 Epigenetic transgenerational actions of endocrine disruptors and male fertility. Science 308 1466-1469. (https://doi.org/10.1126/science.1108190)
Astapova I \& Hollenberg AN 2013 The in vivo role of nuclear receptor corepressors in thyroid hormone action. Biochimica et Biophysica Acta $18303876-3881$.

Auharek SA \& de Franca LR 2010 Postnatal testis development, Sertoli cell proliferation and number of different spermatogonial types in C57BL/6J mice made transiently hypo- and hyperthyroidic during the neonatal period. Journal of Anatomy 216 577-588. (https://doi. org/10.1111/j.1469-7580.2010.01219.x)

Bakke JL, Lawrence NL, Bennett J \& Robinson S 1975 The late effects of neonatal hyperthyroidism upon the feedback regulation of TSH secretion in rats. Endocrinology 97 659-664. (https://doi.org/10.1210/ endo-97-3-659)

Bakke JL, Lawrence NL, Robinson S \& Bennett J 1976 Observations on the untreated progeny of hypothyroid male rats. Metabolism: Clinical and Experimental 25 437-444. (https://doi.org/10.1016/00260495(76)90076-7)

Bakke JL, Lawrence NL, Robinson S \& Bennett J 1977 Endocrine studies in the untreated F1 and F2 progeny of rats treated neonatally with thyroxine. Biology of the Neonate 31 71-83. (https://doi. org/10.1159/000240946)

Barca-Mayo O, Liao XH, Alonso M, Di Cosmo C, Hernandez A, Refetoff S \& Weiss RE 2011 Thyroid hormone receptor alpha and regulation of type 3 deiodinase. Molecular Endocrinology 25 575-583. (https://doi. org/10.1210/me.2010-0213)

Bates JM, St Germain DL \& Galton VA 1999 Expression profiles of the three iodothyronine deiodinases, D1, D2, and D3, in the developing rat. Endocrinology 140 844-851. (https://doi.org/10.1210/ endo.140.2.6537)

Bianco AC, Dumitrescu A, Gereben B, Ribeiro MO, Fonseca TL, Fernandes GW \& Bocco BMLC 2019 Paradigms of dynamic control of thyroid hormone signaling. Endocrine Reviews 40 1000-1047. (https:// doi.org/10.1210/er.2018-00275)

Boulogne B, Habert R \& Levacher C 2003 Regulation of the proliferation of cocultured gonocytes and Sertoli cells by retinoids, triiodothyronine, and intracellular signaling factors: differences between fetal and neonatal cells. Molecular Reproduction and Development 65 194-203. (https://doi.org/10.1002/mrd.10311)

Brent GA, Braverman LE \& Zoeller RT 2007 Thyroid health and the environment. Thyroid 17 807-809. (https://doi.org/10.1089/ thy.2007.1514)

Browning MC, Ford RP, Callaghan SJ \& Fraser CG 1986 Intra- and interindividual biological variation of five analytes used in assessing thyroid function: implications for necessary standards of performance and the interpretation of results. Clinical Chemistry 32 962-966. (https://doi.org/10.1093/clinchem/32.6.962)

Bunick D, Kirby J, Hess RA \& Cooke PS 1994 Developmental expression of testis messenger ribonucleic acids in the rat following propylthiouracilinduced neonatal hypothyroidism. Biology of Reproduction 51 706-713. (https://doi.org/10.1095/biolreprod51.4.706)

Canale D, Agostini M, Giorgilli G, Caglieresi C, Scartabelli G, Nardini V, Jannini EA, Martino E, Pinchera A \& Macchia E 2001 Thyroid hormone receptors in neonatal, prepubertal, and adult rat testis. Journal of Andrology 22 284-288.

Cardoso-Moreira M, Halbert J, Valloton D, Velten B, Chen C, Shao Y, Liechti A, Ascencao K, Rummel C, Ovchinnikova S, et al. 2019 Gene expression across mammalian organ development. Nature $\mathbf{5 7 1}$ 505-509. (https://doi.org/10.1038/s41586-019-1338-5)

Charalambous M \& Hernandez A 2013 Genomic imprinting of the type 3 thyroid hormone deiodinase gene: regulation and developmental implications. Biochimica et Biophysica Acta 1830 3946-3955. (https:// doi.org/10.1016/j.bbagen.2012.03.015)

Chatonnet F, Livera G, Fumel B, FouchÉCourt S \& Flamant F 2014 Direct and indirect consequences on gene expression of a thyroid hormone receptor alpha 1 mutation restricted to Sertoli cells. Molecular Reproduction and Development 81 1159-1166. (https://doi.org/10.1002/ mrd.22437) 
Cooke PS, Zhao YD \& Bunick D 1994 Triiodothyronine inhibits proliferation and stimulates differentiation of cultured neonatal Sertoli cells: possible mechanism for increased adult testis weight and sperm production induced by neonatal goitrogen treatment. Biology of Reproduction 51 1000-1005. (https://doi.org/10.1095/ biolreprod51.5.1000)

Dunn GA, Morgan CP \& Bale TL 2005 Sex-specificity in transgenerational epigenetic programming. Hormones and Behavior 48 1-10.

Dussault JH \& Labrie F 1975 Development of the hypothalamic-pituitarythyroid axis in the neonatal rat. Endocrinology 97 1321-1324. (https:// doi.org/10.1210/endo-97-5-1321)

Evans E, Hogarth C, Mitchell D \& Griswold M 2014 Riding the spermatogenic wave: profiling gene expression within neonatal germ and Sertoli cells during a synchronized initial wave of spermatogenesis in mice. Biology of Reproduction 90 108. (https://doi. org/10.1095/biolreprod.114.118034)

Faraone-Mennella MR, Ferone A, Marino L, Cardone A, Comitato R, Venditti P, Di Meo S \& Farina B 2009 Poly(ADP-ribosyl)ation of proteins and germ cell development in hyperthyroid rat testes. Molecular and Cellular Biochemistry 323 119-129. (https://doi. org/10.1007/s11010-008-9970-7)

Forrest D, Hanebuth E, Smeyne RJ, Everds N, Stewart CL, Wehner JM \& Curran T 1996 Recessive resistance to thyroid hormone in mice lacking thyroid hormone receptor beta: evidence for tissue-specific modulation of receptor function. EMBO Journal 15 3006-3015. (https://doi.org/10.1002/j.1460-2075.1996.tb00664.x)

Forrest D \& Visser TJ 2013 Thyroid hormone signaling. Biochimica et Biophysica Acta 1830 3859. (https://doi.org/10.1016/j. bbagen.2013.03.001)

Fumel B, Froment P, Holzenberger M, Livera G, Monget P \& Fouchecourt S 2015 Expression of dominant-negative thyroid hormone receptor alpha1 in Leydig and Sertoli cells demonstrates no additional defect compared with expression in Sertoli cells only. PLoS ONE 10 e0119392. (https://doi.org/10.1371/journal.pone.0119392)

Fumel B, Guerquin MJ, Livera G, Staub C, Magistrini M, Gauthier C, Flamant F, Guillou F \& Fouchecourt S 2012 Thyroid hormone limits postnatal Sertoli cell proliferation in vivo by activation of its alpha1 isoform receptor (TRalpha1) present in these cells and by regulation of Cdk4/JunD/c-myc mRNA levels in mice. Biology of Reproduction $\mathbf{8 7}$ 16, 1-16, 9. (https://doi.org/10.1095/biolreprod.111.098418)

Fumel B, Roy S, Fouchecourt S, Livera G, Parent AS, Casas F \& Guillou F 2013 Depletion of the p43 mitochondrial T3 receptor increases Sertoli cell proliferation in mice. PLOS ONE 8 e74015. (https://doi. org/10.1371/journal.pone.0074015)

Galton VA, Martinez E, Hernandez A, St Germain EA, Bates JM \& St Germain DL 1999 Pregnant rat uterus expresses high levels of the type 3 iodothyronine deiodinase. Journal of Clinical Investigation 103 979-987. (https://doi.org/10.1172/JCI6073)

Godfrey KM, Gluckman PD \& Hanson MA 2010 Developmental origins of metabolic disease: life course and intergenerational perspectives. Trends in Endocrinology and Metabolism 21 199-205. (https://doi. org/10.1016/j.tem.2009.12.008)

Green CD, Ma Q, Manske GL, Shami AN, Zheng X, Marini S, Moritz L, Sultan C, Gurczynski SJ, Moore BB, et al. 2018 A comprehensive roadmap of murine spermatogenesis defined by single-cell RNA-seq Developmental Cell 46 651.e10-667.e10. (https://doi.org/10.1016/j. devcel.2018.07.025)

Guerrero-Bosagna C \& Skinner MK 2012 Environmentally induced epigenetic transgenerational inheritance of phenotype and disease. Molecular and Cellular Endocrinology 354 3-8. (https://doi. org/10.1016/j.mce.2011.10.004)

Guo J, Nie X, Giebler M, Mlcochova H, Wang Y, Grow EJ, DonorConnect, Kim R, Tharmalingam M, Matilionyte G, et al. 2020 The dynamic transcriptional cell atlas of testis development during human puberty. Cell Stem Cell 26 262-276. (https://doi.org/10.1016/j. stem.2019.12.005)
Hernandez A 2005 Structure and function of the type 3 deiodinase gene. Thyroid 15 865-874. (https://doi.org/10.1089/thy.2005.15.865)

Hernandez A 2013 Genomic imprinting of the type 3 thyroid hormone deiodinase gene: regulation and developmental implications. Biochimica et Biophysica Acta 1830 3946-3955.

Hernandez A 2018a Thyroid hormone deiodination and action in the gonads. Current Opinion in Endocrine and Metabolic Research 2 18-23. (https://doi.org/10.1016/j.coemr.2018.01.010)

Hernandez A 2018b Thyroid hormone role and economy in the developing testis. Vitamins and Hormones 106 473-500. (https://doi. org/10.1016/bs.vh.2017.06.005)

Hernandez A, Fiering S, Martinez E, Galton VA \& St Germain D 2002 The gene locus encoding iodothyronine deiodinase type 3 (Dio3) is imprinted in the fetus and expresses antisense transcripts. Endocrinology 143 4483-4486. (https://doi.org/10.1210/en.2002-220800)

Hernandez A, Martinez ME, Fiering S, Galton VA \& St Germain D 2006 Type 3 deiodinase is critical for the maturation and function of the thyroid axis. Journal of Clinical Investigation 116 476-484. (https://doi. org/10.1172/JCI26240)

Hernandez A, Martinez ME, Liao XH, Van Sande J, Refetoff S, Galton VA \& St Germain DL 2007 Type 3 deiodinase deficiency results in functional abnormalities at mutiple levels of the thyroid axis. Endocrinology 148 5680-5687. (https://doi.org/10.1210/en.2007-0652)

Hernandez A, Morte B, Belinchon MM, Ceballos A \& Bernal J 2012 Critical role of types 2 and 3 deiodinases in the negative regulation of gene expression by T(3)in the mouse cerebral cortex. Endocrinology 153 2919-2928. (https://doi.org/10.1210/en.2011-1905)

Heuer H \& Visser TJ 2009 Minireview: pathophysiological importance of thyroid hormone transporters. Endocrinology 150 1078-1083. (https:// doi.org/10.1210/en.2008-1518)

Heuer H \& Visser TJ 2013 The pathophysiological consequences of thyroid hormone transporter deficiencies: insights from mouse models. Biochimica et Biophysica Acta 1830 3974-3978. (https://doi. org/10.1016/j.bbagen.2012.04.009)

Hochberg Z, Feil R, Constancia M, Fraga M, Junien C, Carel JC, Boileau P, Le Bouc Y, Deal CL, Lillycrop K, et al. 2011 Child health, developmental plasticity, and epigenetic programming. Endocrine Reviews 32 159-224. (https://doi.org/10.1210/er.2009-0039)

Holsberger DR \& Cooke PS 2005 Understanding the role of thyroid hormone in Sertoli cell development: a mechanistic hypothesis. Cell and Tissue Research 322 133-140. (https://doi.org/10.1007/s00441005-1082-z)

Holsberger DR, Buchold GM, Leal MC, Kiesewetter SE, O’Brien DA, Hess RA, Franca LR, Kiyokawa H \& Cooke PS 2005a Cell-cycle inhibitors p27Kip1 and p21Cip1 regulate murine Sertoli cell proliferation. Biology of Reproduction 72 1429-1436. (https://doi. org/10.1095/biolreprod.105.040386)

Holsberger DR, Kiesewetter SE \& Cooke PS 2005b Regulation of neonatal Sertoli cell development by thyroid hormone receptor alpha1. Biology of Reproduction 73 396-403. (https://doi.org/10.1095/ biolreprod.105.041426)

Huang SA, Dorfman DM, Genest DR, Salvatore D \& Larsen PR 2003 Type 3 iodothyronine deiodinase is highly expressed in the human uteroplacental unit and in fetal epithelium. Journal of Clinical Endocrinology and Metabolism 88 1384-1388. (https://doi.org/10.1210/ jc.2002-021291)

Hutka M, Smith LB \& Mitchell RT 2017 Xenotransplantation as a model for human testicular development. Differentiation: Research in Biological Diversity 97 44-53. (https://doi.org/10.1016/j. diff.2017.09.001)

Jannini EA, Olivieri M, Francavilla S, Gulino A, Ziparo E \& D'Armiento M 1990 Ontogenesis of the nuclear 3,5,3'-triiodothyronine receptor in the rat testis. Endocrinology 126 2521-2526. (https://doi.org/10.1210/ endo-126-5-2521)

Jannini EA, Dolci S, Ulisse S \& Nikodem VM 1994 Developmental regulation of the thyroid hormone receptor alpha 1 mRNA expression https://joe.bioscientifica.com

https://doi.org/10.1530/JOE-19-0550 (c) 2020 Society for Endocrinology Published by Bioscientifica Ltd. Printed in Great Britain 
in the rat testis. Molecular Endocrinology 8 89-96. (https://doi. org/10.1210/mend.8.1.8152433)

Jirtle RL \& Skinner MK 2007 Environmental epigenomics and disease susceptibility. Nature Reviews: Genetics 8 253-262. (https://doi. org/10.1038/nrg2045)

Kimura T \& Furudate S 1996 Pituitary GH and prolactin deficiency and testis enlargement in hypothyroid rats caused by goitrogen methimazole. Experimental Animals 45 369-375. (https://doi. org/10.1538/expanim.45.369)

Kirby JD, Mankar MV, Hardesty D \& Kreider DL 1996 Effects of transient prepubertal 6-N-propyl-2-thiouracil treatment on testis development and function in the domestic fowl. Biology of Reproduction $\mathbf{5 5}$ 910-916. (https://doi.org/10.1095/biolreprod55.4.910)

Kobayashi K, Kubota H, Hojo R \& Miyagawa M 2014 Dose-dependent effects of perinatal hypothyroidism on postnatal testicular development in rat offspring. Journal of Toxicological Sciences 39 867-874. (https://doi.org/10.2131/jts.39.867)

Koch L 2014a Disease genetics: insights into missing heritability. Nature Reviews: Genetics 15 218. (https://doi.org/10.1038/nrg3713)

Koch L 2014b Epigenetics: an epigenetic twist on the missing heritability of complex traits. Nature Reviews: Genetics 15 218. (https://doi. org/10.1038/nrg3698)

Law NC, Oatley MJ \& Oatley JM 2019 Developmental kinetics and transcriptome dynamics of stem cell specification in the spermatogenic lineage. Nature Communications 102787 . (https://doi. org/10.1038/s41467-019-10596-0)

Lee SH, Wray NR, Goddard ME \& Visscher PM 2011 Estimating missing heritability for disease from genome-wide association studies. American Journal of Human Genetics 88 294-305. (https://doi. org/10.1016/j.ajhg.2011.02.002)

Levine H, Jorgensen N, Martino-Andrade A, Mendiola J, Weksler-Derri D, Mindlis I, Pinotti R \& Swan SH 2017 Temporal trends in sperm count: a systematic review and meta-regression analysis. Human Reproduction Update 23 646-659. (https://doi.org/10.1093/humupd/dmx022)

Makela JA, Koskenniemi JJ, Virtanen HE \& Toppari J 2019 Testis development. Endocrine Reviews 40 857-905. (https://doi.org/10.1210/ er.2018-00140)

Maran RR, Arunakaran J, Jeyaraj DA, Ravichandran K, Ravisankar B \& Aruldhas MM 2000 Transient neonatal hypothyroidism alters plasma and testicular sex steroid concentration in puberal rats. Endocrine Research 26 411-429. (https://doi.org/10.3109/07435800009066177)

Martin SM \& Moberg GP 1981 Effects of early neonatal thyroxine treatment on development of the thyroid and adrenal axes in rats. Life Sciences 29 1683-1688. (https://doi.org/10.1016/00243205(81)90071-0)

Martinez ME, Cox DF, Youth BP \& Hernandez A 2016a Genomic imprinting of DIO3, a candidate gene for the syndrome associated with human uniparental disomy of chromosome 14. European Journal of Human Genetics 24 1617-1621. (https://doi.org/10.1038/ ejhg.2016.66)

Martinez ME, Karaczyn A, Stohn JP, Donnelly WT, Croteau W, Peeters RP, Galton VA, Forrest D, St Germain D \& Hernandez A 2016b The type 3 deiodinase is a critical determinant of appropriate thyroid hormone action in the developing testis. Endocrinology 157 1276-1288. (https:// doi.org/10.1210/en.2015-1910)

Martinez ME, Duarte CW, Stohn JP, Karaczyn A, Wu Z, DeMambro VE \& Hernandez A 2018 Thyroid hormone influences brain gene expression programs and behaviors in later generations by altering germ line epigenetic information. Molecular Psychiatry [epub]. (https://doi. org/10.1038/s41380-018-0281-4)

Martinez ME, Lary CW, Karaczyn AA, Griswold MD \& Hernandez A 2019 Spermatogonial type 3 deiodinase regulates thyroid hormone target genes in developing testicular somatic cells. Endocrinology 160 2929-2945. (https://doi.org/10.1210/en.2019-00259)

McClelland KS, Bell K, Larney C, Harley VR, Sinclair AH, Oshlack A, Koopman P \& Bowles J 2015 Purification and transcriptomic analysis of mouse fetal Leydig cells reveals candidate genes for specification of gonadal steroidogenic cells. Biology of Reproduction 92 145. (https:// doi.org/10.1095/biolreprod.115.128918)

McLachlan SM \& Rapoport B 2014 Breaking tolerance to thyroid antigens: changing concepts in thyroid autoimmunity. Endocrine Reviews 35 59-105. (https://doi.org/10.1210/er.2013-1055)

Meroni SB, Galardo MN, Rindone G, Gorga A, Riera MF \& Cigorraga SB 2019 Molecular mechanisms and signaling pathways involved in Sertoli cell proliferation. Frontiers in Endocrinology 10 224. (https://doi. org/10.3389/fendo.2019.00224)

Morreale de Escobar G, Calvo R, Obregon MJ \& Escobar Del Rey F 1990 Contribution of maternal thyroxine to fetal thyroxine pools in normal rats near term. Endocrinology 126 2765-2767. (https://doi. org/10.1210/endo-126-5-2765)

Ng L, Goodyear RJ, Woods CA, Schneider MJ, Diamond E, Richardson GP, Kelley MW, St Germain DL, Galton VA \& Forrest D 2004 Hearing loss and retarded cochlear development in mice lacking type 2 iodothyronine deiodinase. PNAS 101 3474-3479. (https://doi. org/10.1073/pnas.0307402101)

Nilsson EE \& Skinner MK 2015 Environmentally induced epigenetic transgenerational inheritance of disease susceptibility. Translational Research 165 12-17. (https://doi.org/10.1016/j.trsl.2014.02.003)

Oluwole OA, Bartlewski PM \& Hahnel A 2013 Relationships of serum thyroid hormones and follicle-stimulating hormone concentrations to Sertoli cell differentiation during the first wave of spermatogenesis in euthyroid ram lambs. Reproductive Biology 13 150-160. (https://doi. org/10.1016/j.repbio.2013.04.001)

Palmero S, Prati M, Bolla F \& Fugassa E 1995 Tri-iodothyronine directly affects rat Sertoli cell proliferation and differentiation. Journal of Endocrinology 145 355-362. (https://doi.org/10.1677/joe.0.1450355)

Pascual A \& Aranda A 2013 Thyroid hormone receptors, cell growth and differentiation. Biochimica et Biophysica Acta 1830 3908-3916. (https://doi.org/10.1016/j.bbagen.2012.03.012)

Rao JN, Liang JY, Chakraborti P \& Feng P 2003 Effect of thyroid hormone on the development and gene expression of hormone receptors in rat testes in vivo. Journal of Endocrinological Investigation 26 435-443. (https://doi.org/10.1007/BF03345199)

Rijntjes E, Wientjes AT, Swarts HJ, de Rooij DG \& Teerds KJ 2008 Dietary-induced hyperthyroidism marginally affects neonatal testicular development. Journal of Andrology 29 643-653. (https://doi. org/10.2164/jandrol.108.005108)

Rijntjes E, Swarts HJ, Anand-Ivell R \& Teerds KJ 2009 Prenatal induced chronic dietary hypothyroidism delays but does not block adult-type Leydig cell development. American Journal of Physiology: Endocrinology and Metabolism 296 E305-E314. (https://doi.org/10.1152/ ajpendo.90750.2008)

Rodgers AB, Morgan CP, Bronson SL, Revello S \& Bale TL 2013 Paternal stress exposure alters sperm microRNA content and reprograms offspring HPA stress axis regulation. Journal of Neuroscience 33 9003-9012. (https://doi.org/10.1523/JNEUROSCI.0914-13.2013)

Rodgers AB, Morgan CP, Leu NA \& Bale TL 2015 Transgenerational epigenetic programming via sperm microRNA recapitulates effects of paternal stress. PNAS 112 13699-13704. (https://doi.org/10.1073/ pnas.1508347112)

Ruiz de Oña C, Morreale de Escobar G, Calvo R, Escobar del Rey F \& Obregón MJ 1991 Thyroid hormones and 5'-deiodinase in the rat fetus late in gestation: effects of maternal hypothyroidism. Endocrinology 128 422-432. (https://doi.org/10.1210/endo-128-1-422)

Sakai Y, Yamashina S \& Furudate S 2004 Developmental delay and unstable state of the testes in the rdw rat with congenital hypothyroidism. Development, Growth and Differentiation 46 327-334. (https://doi.org/10.1111/j.1440-169x.2004.00748.x)

Sarkar D \& Singh SK 2017a Effect of neonatal hypothyroidism on prepubertal mouse testis in relation to thyroid hormone receptor alpha 1 (THRalpha1). General and Comparative Endocrinology 251 109-120. (https://doi.org/10.1016/j.ygcen.2016.08.001) 
Sarkar D \& Singh SK 2017b Neonatal hypothyroidism affects testicular glucose homeostasis through increased oxidative stress in prepubertal mice: effects on GLUT3, GLUT8 and Cx43. Andrology 5 749-762. (https://doi.org/10.1111/andr.12363)

Skinner MK 2007 Endocrine disruptors and epigenetic transgenerational disease etiology. Pediatric Research 61 48R-50R. (https://doi. org/10.1203/pdr.0b013e3180457671)

Skinner MK 2016 Endocrine disruptors in 2015: epigenetic transgenerational inheritance. Nature Reviews: Endocrinology 12 68-70. (https://doi.org/10.1038/nrendo.2015.206)

Srichomkwun P, Anselmo J, Liao XH, Hones GS, Moeller LC, AlonsoSampedro M, Weiss RE, Dumitrescu AM \& Refetoff S 2017 Fetal exposure to high maternal thyroid hormone levels causes central resistance to thyroid hormone in adult humans and mice. Journal of Clinical Endocrinology and Metabolism 102 3234-3240. (https://doi. org/10.1210/jc.2017-00019)

St Germain DL, Galton VA \& Hernandez A 2009 Defining the roles of iodohyronine deiodinases: current concepts and challenges. Endocrinology 150 1097-1107. (https://doi.org/10.1210/ en.2008-1588)

Stohn JP, Martinez ME \& Hernandez A 2016 Decreased anxiety- and depression-like behaviors and hyperactivity in a type 3 deiodinasedeficient mouse showing brain thyrotoxicosis and peripheral hypothyroidism. Psychoneuroendocrinology 74 46-56. (https://doi. org/10.1016/j.psyneuen.2016.08.021)

Tagami T, Nakamura H, Sasaki S, Mori T, Yoshioka H, Yoshida H \& Imura H 1990 Immunohistochemical localization of nuclear 3,5,3'-triiodothyronine receptor proteins in rat tissues studied with antiserum against C-ERB A/T3 receptor. Endocrinology 127 1727-1734. (https://doi.org/10.1210/endo-127-4-1727)

Tharmalingam MD, Jorgensen A \& Mitchell RT 2018 Experimental models of testicular development and function using human tissue and cells. Molecular and Cellular Endocrinology 468 95-110. (https:// doi.org/10.1016/j.mce.2017.12.011)

Tousson E, Ali EM, Ibrahim W \& Mansour MA 2011 Proliferating cell nuclear antigen as a molecular biomarker for spermatogenesis in PTUinduced hypothyroidism of rats. Reproductive Sciences 18 679-686. (https://doi.org/10.1177/1933719110395401)

Tsai CE, Lin SP, Ito M, Takagi N, Takada S \& Ferguson-Smith AC 2002 Genomic imprinting contributes to thyroid hormone metabolism in the mouse embryo. Current Biology 12 1221-1226. (https://doi. org/10.1016/s0960-9822(02)00951-x)

van Haaster LH, de Jong FH, Docter R \& de Rooij DG 1993 High neonatal triiodothyronine levels reduce the period of Sertoli cell proliferation and accelerate tubular lumen formation in the rat testis, and increase serum inhibin levels. Endocrinology 133 755-760. (https://doi. org/10.1210/endo.133.2.8344214)

Vanacker JM, Bonnelye E, Delmarre C \& Laudet V 1998 Activation of the thyroid hormone receptor alpha gene promoter by the orphan nuclear receptor ERR alpha. Oncogene 17 2429-2435. (https://doi. org/10.1038/sj.onc.1202167)

Wagner MS, Wajner SM \& Maia AL 2008 The role of thyroid hormone in testicular development and function. Journal of Endocrinology 199 351-365. (https://doi.org/10.1677/JOE-08-0218)

Waterland RA, Travisano M \& Tahiliani KG 2007 Diet-induced hypermethylation at agouti viable yellow is not inherited transgenerationally through the female. FASEB Journal 21 3380-3385. (https://doi.org/10.1096/fj.07-8229com)

Zambrano E, Martinez-Samayoa PM, Bautista CJ, Deas M, Guillen L, Rodriguez-Gonzalez GL, Guzman C, Larrea F \& Nathanielsz PW 2005 Sex differences in transgenerational alterations of growth and metabolism in progeny (F2) of female offspring (F1) of rats fed a low protein diet during pregnancy and lactation. Journal of Physiology 566 225-236. (https://doi.org/10.1113/jphysiol.2005.086462)

Received in final form 15 January 2020

Accepted 24 January 2020

Accepted Manuscript published online 24 January 2020 (c) 2020 Society for Endocrinology Published by Bioscientifica Ltd. 